\title{
Selection of diazotrophic bacterial communities in biological sand filter mesocosms used for the treatment of phenolic-laden wastewater
}

Jean-Baptiste Ramond, Pamela J. Welz, Marla I. Tuffin, Stephanie G. Burton and Don A. Cowan

\begin{abstract}
Agri effluents such as winery or olive mill waste-waters are characterized by high phenolic concentrations. These compounds are highly toxic and generally refractory to biodegradation. Biological sand filters (BSFs) represent inexpensive, environmentally friendly, and sustainable wastewater treatment systems which rely vastly on microbial catabolic processes. Using denaturing gradient gel electrophoresis and terminal-restriction fragment length polymorphism, this study aimed to assess the impact of increasing concentrations of synthetic phenolic-rich wastewater, ranging from $96 \mathrm{mg} \mathrm{L}^{-1}$ gallic acid and $138 \mathrm{mg} \mathrm{L}^{-1}$ vanillin (i.e., a total chemical oxygen demand (COD) of $234 \mathrm{mg} \mathrm{L}^{-1}$ ) to 2,400 mg $\mathrm{L}^{-1}$ gallic acid and $3,442 \mathrm{mg} \mathrm{L}^{-1}$ vanillin $\left(5,842 \mathrm{mg} \mathrm{COD} \mathrm{L}^{-1}\right)$, on bacterial communities and the specific functional diazotrophic community from BSF mesocosms. This amendment procedure instigated efficient BSF phenolic removal, significant modifications of the bacterial communities, and notably led to the selection of a phenolicresistant and less diverse diazotrophic community. This suggests that bioavailable $\mathrm{N}$ is crucial in the functioning of biological treatment processes involving microbial communities, and thus that functional alterations in the bacterial communities in BSFs ensure provision of sufficient bioavailable nitrogen for the degradation of wastewater with a high $\mathrm{C} / \mathrm{N}$ ratio.
\end{abstract}

\section{Introduction}

In developing countries, agri-industrial wastewaters are frequently discharged into aquatic environments without (pre)treatments due to the lack of treatment facilities [10]. The first corollary of such practices is that water resources become contaminated and therefore unsuitable for human consumption, land irrigation, fish production, and/or recreational activities. The second is that this practice constitutes a major constraint on the country's sustainable development [10]. For example, agri wastewaters are generally organic- and/or nutrient-rich effluents which can dramatically affect water quality, and notably lead to eutrophication of water systems [24].

South Africa is a water-scarce, developing country with an important and established wine industry [21] and with a young, emerging olive farming sector [26], both mainly situated 
in the Western Cape Province. Winery wastewater (WW) and olive mill wastewater $(\mathrm{OMWW})$ are variable in nature but generally characterized by elevated chemical oxygen demand (COD) levels (up to $25 \mathrm{~g} \mathrm{~L}^{-1}$ and $170 \mathrm{~g} \mathrm{~L}^{-1}$, respectively) and contaminated with (poly)phenolic compounds such as tannins [16, 29]. The (poly)phenolics are highly toxic and persist in the environment due to slow biodegradation rates [14, 23]. Therefore, strategies must be implemented to reduce the phenolic content of such waste-waters prior to discharge and/or re-use; the latter being of crucial importance in countries subject to water shortages, such as South Africa [10].

Among the various remediation (pre)treatment processes studied to treat organic-rich effluents, the use of constructed/ treatment wetlands (C/TW) has been extensively investigated (for reviews, see [1, 6, 9, 27]). C/TW systems are ideal for developing countries as they are cost-effective, self-sustainable, low in maintenance [10], and effective in treating simple and/or complex organic-rich contaminants such as WW and OMWW [8, 14]. The treatment capacity of these systems relies on the synergism between plants, soil, and microbial communities, thus involving abiotic (soil substratum) and biotic (plants and microorganisms) remediation mechanisms.

Phenolic compounds are phytotoxic [14] and the roles of plants in CW COD-removal capacity is controversial [27]. Therefore, in this study, the impact of artificial phenolic-laden wastewater on an unplanted CW mesocosm, or biological sand filter (BSF), was investigated with an emphasis on the bacterial communities present in the BSF. Microorganisms can actively degrade phenolic compounds with several relevant enzymes being widely distributed in the microbial tree-of-life (e.g., oxygenases, dehydrogenases, laccases, peroxidases $[7,11])$. However, phenolic compounds can also hamper or inhibit microbial activity and growth [18].

We have previously shown that BSF microbial communities exposed to incremental concentrations of ethanol become more tolerant of the contaminant than communities exposed to a higher concentration from outset, a phenomenon classically termed 'microbial acclimation' [28]. In this study, we used the more toxic and recalcitrant compounds, gallic acid, and vanillin, and incrementally increased the phenolic concentration of artificial wastewater over a period of 9 weeks. Microbial community structure evolution was monitored using denaturing gradient gel electrophoresis (DGGE) analysis of the 16S rRNA gene and phenolic-selected bacterial taxa were identified with post-electrophoretic phylogenetic analysis. Moreover, it has recently been demonstrated that the addition of bioavailable nutrients to organic-rich effluents (particularly nitrogen) enhanced the remediatory performances of treatment BSFs [20] and that nitrogen-fixing bacteria are selected in organic-contaminated environments [2], suggesting that bioavailable $\mathrm{N}$ and/or diazotrophic communities are crucial in such environments. Therefore, we studied the evolution of the BSF diazotrophic community using terminalrestriction fragment length polymorphism (T-RFLP) with the nifH gene as phylogenetic marker [17].

\section{http://repository.uwc.ac.za}




\section{Material and Method}

Setup and Feeding/Amendment Procedures of the Pilot-Scale Biological Sand Filters The BSF mesocosms consisted of two identical polyethylene tanks (length $173 \mathrm{~cm} /$ width 106 $\mathrm{cm} /$ depth $30 \mathrm{~cm}$ ), each containing river sand ( $1 \%$ clay, $7 \%$ silt, $4 \%$ fine sand, $12 \%$ medium sand, and $76 \%$ coarse sand), to a volume of $\sim 0.5 \mathrm{~m}^{3}$, void space of $0.08 \mathrm{~m}^{3}$ and a depth of $0.3 \mathrm{~m}$, and were set up as previously described [19, 28]. The BSFs were maintained in an outdoor, undercover environment in order to avoid exposure to precipitation events. The systems were operated in a hybrid mode of vertical and horizontal subsurface flow. Biweekly inundation (i.e., intermittent flow fed BSF), followed by gradient-directed drainage, ensured that the mode of operation was biased towards classical vertical subsurface flow. This mode of operation is considered to favor aerobic microbial processes and thus increase C/BOD removal potential [5].

One replicate (A) served as a control and the other (B) served as the test BSF. Both received a bi-weekly basal influent solution consisting of $0.3 \mathrm{~g}$ yeast extract and $0.3 \mathrm{~g} \mathrm{D}(+)$ glucose dissolved in $12.5 \mathrm{~L}$ tap water, for the duration of a 3-month equilibration period [19] and experimental periods. This basal nutrient amendment procedure provided a $\mathrm{C} / \mathrm{N} / \mathrm{P}$ ratio of 32:7:1 (influent $\mathrm{COD}=24 \mathrm{mg} \mathrm{L} \mathrm{L}^{-1}, \mathrm{~N}=5.5 \mathrm{mg} \mathrm{L}^{-1}$ and $\mathrm{P}=0.76 \mathrm{mg} \mathrm{L}^{-1}$ ). This low nutrient supply was designed to maintain an oligotrophic state, as oligotrophic systems are more reactive to changes in nutrient status such as contamination with wastewater [25]. During the experimental period, BSF B was amended with gallic acid and vanillin for 9 weeks, with the concentration being increased every 3 weeks [29]. Initially, $96 \mathrm{mg} \mathrm{L}^{-1}$ gallic acid and $138 \mathrm{mg} \mathrm{L}^{-1}$ vanillin was added (day o to week 3), followed by $488 \mathrm{mg} \mathrm{L}^{-1}$ gallic acid and $688 \mathrm{mg} \mathrm{L}^{-1}$ vanillin (weeks 4 to 6 ) and finally $2,400 \mathrm{mg} \mathrm{L}^{-1}$ gallic acid and $3,442 \mathrm{mg} \mathrm{L}^{-1}$ vanillin (weeks 7 to 9). The resultant corresponding COD values were 234, 1,176 , and $5,842 \mathrm{mg} \mathrm{L}^{-1}$ respectively.

\section{SedimentSampling}

A 30-mm internal diameter PVC sediment corer was used to recover samples without disturbance of the sediment stratification. Triplicate sample cores were taken from the inlet and the outlet of each CW at the start of the experiment (day o) and after 3,6, and 9 weeks of the experiment. The surface $(0-3 \mathrm{~cm})$ and deep $\left(15^{-}-20 \mathrm{~cm}\right)$ fractions of each sample were thoroughly mixed and $\sim 1 \mathrm{~g}$ wet weight sediment was retained at -80 ${ }^{\circ} \mathrm{C}$ for subsequent molecular analysis.

\section{Metagenomic DNA Extraction and Quantification}

Metagenomic DNA was extracted from $0.5 \mathrm{~g}$ of samples (wet weight) with the Powersoil DNA isolation kit according to the manufacturer's instructions (Mo Bio Laboratories, USA). The concentration of the DNA samples was measured with a NanoDrop spectrophotometer (NanoDrop Technologies, Montchanin, DE, USA).

\section{http://repository.uwc.ac.za}




\section{PCR Amplification, Purification, and Restriction 16S rRNA Gene}

All polymerase chain reactions (PCR) were carried out in a Perkin Elmer Thermocycler (Gene Amp PCR system 6700). Bacterial 16S rRNA encoding genes were amplified by PCR using the universal primers E9F (5'-GAGTTTGATCCT GGCTCAG- $\left.3^{\prime}\right)$ and U1510R (5'GGTTACCTTGTTAC GACTT- $3^{\prime}$ ). PCR was carried out in $50-\mu l$ reaction volumes. Each reaction contained $1 \mathrm{X}$ PCR buffer, $0.2 \mathrm{U}$ DreamTaq ${ }^{\mathrm{TM}}$ polymerase (Fermentas, USA), 200 $\mu \mathrm{M}$ of each dNTP, 0.5 $\mu \mathrm{M}$ of each primer, $0.1 \%$ BSA and between 5 and $10 \mathrm{ng}$ of metagenomic DNA. PCR amplification was carried out as follows: 4 min at $94{ }^{\circ} \mathrm{C}$ for denaturation; 30 cycles of $30 \mathrm{~s}$ at $94{ }^{\circ} \mathrm{C}, 30 \mathrm{~s}$ annealing at $52{ }^{\circ} \mathrm{C}$, and $105 \mathrm{~s}$ at $72{ }^{\circ} \mathrm{C}$; and a final elongation step of $10 \mathrm{~min}$ at $72{ }^{\circ} \mathrm{C}$. A nested-PCR was performed using $1 \mu \mathrm{L}$ of the amplicon obtained with the 16S rRNA primer set E9F/U1510R with the primer set $341 \mathrm{~F}-\mathrm{GC}$ ( $5^{\prime}$ CCTACGGGAGGCAGCAG-3')/514R (5'-ATTACCGC GGCTGCTG-3') as follows [13]: 94 ${ }^{\circ} \mathrm{C}$ for $4 \mathrm{~min}, 20$ cycles $-94{ }^{\circ} \mathrm{C}$ for $45 \mathrm{~s}, 65{ }^{\circ} \mathrm{C}$ for $45 \mathrm{~s}, 72{ }^{\circ} \mathrm{C}$ for 60 s additional 20 cycles $-94{ }^{\circ} \mathrm{C}$ for $30 \mathrm{~s}, 55^{\circ} \mathrm{C}$ for $30 \mathrm{~s}, 72{ }^{\circ} \mathrm{C}$ for $60 \mathrm{~s}$, and a final elongation step at $72{ }^{\circ} \mathrm{C}$ for 10 min. PCR amplification with $341 \mathrm{f}-\mathrm{GC} / 534 \mathrm{r}$ was performed by using a $50 \mu \mathrm{l}$ total volume mixture containing 0.2 U DreamTaq $^{\mathrm{TM}}$ polymerase (Fermentas, USA), 1X PCR Buffer, 200 $\mu \mathrm{M}$ of each dNTP, $0.5 \mu \mathrm{M}$ of each primer and $0.1 \%$ BSA. For the DGGE analysis, a 40mer GC-clamp (CGCCCGCCGC GCGCGGCGGGCGGGGCGGGGGCACGGGGGG) was added to the $5^{\prime}$ ends of the forward primers $341 \mathrm{~F}$.

\section{Bacterial nifH Gene}

PCR amplification of the bacterial nifH gene was performed using the primer set PolF $\left(5^{\prime}-\right.$ TGCGA[C/T]CC[G/C $]$ AA $\quad[$ A/G $]$ GC[C/G/T]GACTC-3')/PolR $\quad\left(5^{\prime}\right.$-AT[G/C $]$ GCCATC AT[C/T]TC[A/G]CCGGA-3') and the PCR conditions previously described [17]. For T-RFLP analyses (Section 2.6) the forward primer PolF was 5'-end FAM-labeled, and the PCR products were purified using the NucleoSpin purification kit as directed by the supplier (GE Healthcare, UK). Purified PCR products (200 ng) were digested with the restriction enzyme HaeIII at $37^{\circ} \mathrm{C}$ overnight.

\section{Denaturing Gradient Gel Electrophoresis}

PCR amplicons obtained with the nested primer sets (341 F- GC/534R) were analyzed by DGGE. Amplicons were separated on 16.5/16.5 cm, $1 \mathrm{~mm} 9 \%$ (w/v) polyacrylamide (37.5:1 acrylamide/bisacrylamide) gels with varying denaturing gradients (100 \% denaturant was $7 \mathrm{M}$ urea and $40 \%$ (v/v) formamide). Gels were prepared using a gradient former and were cast according to manufacturer's specifications (BioRad Laboratories, USA). Electrophoresis was performed using the DCode DGGE system (BioRad Laboratories, Inc. USA) and was carried out at $100 \mathrm{~V}$ for $16 \mathrm{~h}$ at $60{ }^{\circ} \mathrm{C}(1,600 \mathrm{Vh})$ in $1 \mathrm{X}$ TAE buffer. Gels were stained in $0.5 \mu \mathrm{g} \mathrm{mL}{ }^{-1}$ EtBr in $1 \mathrm{X}$ TAE for 20 min and visualized on an AlphaImager 3400 imaging system.

DGGE gel pictures were processed with Gelcompar II 5.0 software (Applied Maths, Belgium). The DGGE banding patterns were compiled and band matching was performed in order to obtain large data matrixes based on the presence/absence of DGGE bands. The complete

\section{http://repository.uwc.ac.za}


banding pattern of each profile was considered for comparison. Similarity between fingerprints was calculated with the cosine coefficient and Ward's hierarchical clustering algorithm.

DGGE bands affected by experimental phenolic additions (i.e., only present and/or intense in the phenolic contaminated bacterial community structure) were excised using sterile surgical blades and eluted in $50 \mu \mathrm{L}$ of filter-sterilized water at $4{ }^{\circ} \mathrm{C}$ overnight. One microlitre of the supernatant was then re-analyzed by PCR and DGGE to eliminate any residual contamination by 'parasite' bands. The remaining PCR products $(\sim 25 \mu \mathrm{L})$ were purified using the GFX ${ }^{\mathrm{TM}}$ PCR DNA and gel band purification kit as directed by the supplier (GE Healthcare, UK). The purified PCR products from DGGE bands were sequenced with a Hitachi 3730xl DNA Analyzer (Applied Biosystems).

\section{nifH T-RFLP}

The evolution of the nitrogen-fixing bacterial community structure was assessed by T-RFLP fingerprinting using the nifH gene as a marker. The precise length of T-RFs was determined by capillary electrophoresis according to the molecular weight standard GS500 and with an acceptable error of $\pm 1 \mathrm{bp}$. T-RFLP patterns and quality were analyzed using the freeware PeakScanner ${ }^{\mathrm{TM}}$ (version 1.0) (Applied Biosystems, https://products.appliedbiosystems.com). Peak height was used to characterize each unique T-RF, and valid T-RF peaks (between 35 and $360 \mathrm{bp}$ ) from triplicate T-RFLP profiles were identified, compiled, and aligned to produce large data matrices using the online software TREX (http:// trex.biohpc.org/) [4]. T-RFs with intensities lower than $1 \%$ which may have originated from background interferences were excluded from the matrixes.

\section{Statistical Analysis}

All T-RFLP statistical analyses were performed with the software Primer 6 (Primer-E Ltd, UK). To visualize the effect of phenolics on the diazotrophic bacterial community profile, non-metric multidimensional scaling (MDS) plots were created using Bray-Curtis similarity matrices of square root transformed T-RFLP data reflecting relative operational taxonomic unit (OTU) abundance. Two-dimensional MDS plots were used, where the distance between points reflects the degree of similarity between the microbial community profiles in the samples. In these plots, the percentage of similarity determined by cluster analysis is displayed by ellipses. An analysis of similarity (ANOSIM), performed on the resemblance matrix, was used to test for differences in bacterial community structure between predefined groups [3]. The Shannon $\left(\mathrm{H}^{\prime}=-\Sigma\right.$ pi/lnpi) and eveness $\left(\mathrm{E}=\mathrm{H}^{\prime} / \mathrm{lnS}\right)$ diversity indexes were calculated from the nifH gene T-RFLP profiles. pi corresponds to the relative abundance of T-RFs "i" in the T-RFLP profiles, and $\mathrm{S}$ to the richness; i.e., the total number of T-RFs detected. 
Fig. 1 Dendrograms of DGGE pattern similarity of surface (a) and deep (b) sediment bacterial communities of the biological sand filters. $i / o$ : inlet/outlet. $D 0$, day $0 ; W 3$, week $3 ; W 6$, week 6 ; W9, week 9 a

\section{Similarity (\%)}

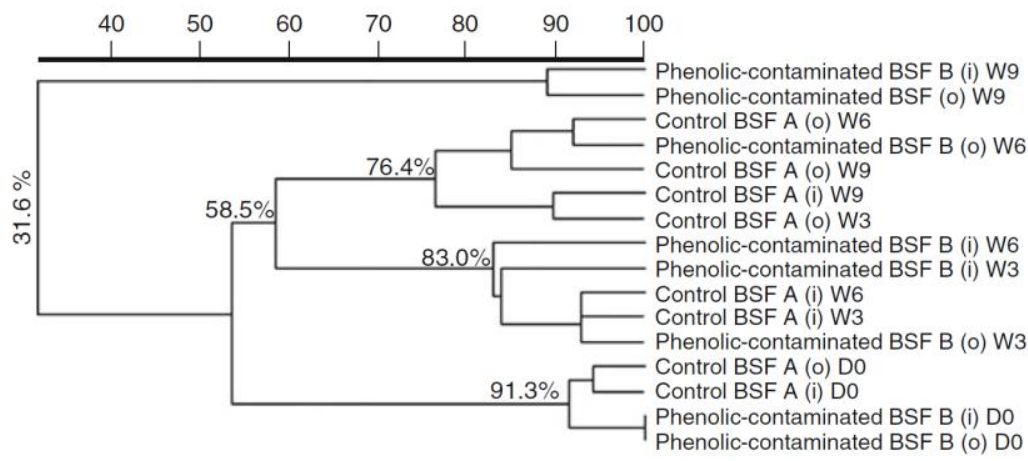

b Similarity $(\%)$

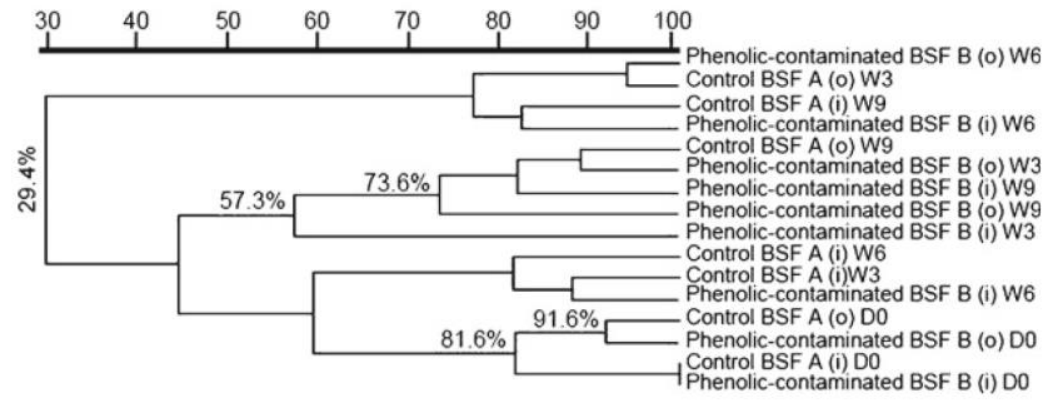

\section{Results and Discussion}

In BSFs, the sediment matrix (abiotic) and the microbial communities (biotic) are synergistically involved in the bio-remediation processes. Indeed, in a sand-column experiment biotic and abiotic mechanisms each accounted for around $50 \%$ of phenolic removal [29].

Table 1 Average removal rate and influent and effluent wastewater qualities for the phenolic-amended CW B during 112 days

\begin{tabular}{lcccc}
\hline Parameter & Week & Influent & Effluent & Removal $^{\mathrm{a}}(\%)$ \\
\hline COD $\left(\mathrm{mg} \mathrm{L}^{-1}\right)$ & $0-3$ & 234.0 & $15.7 \pm 4.2$ & 93.4 \\
& $3-6$ & $1,176.0$ & $62.0 \pm 18.3$ & 95.4 \\
Total phenols (mg GAE L & & $573.6 \pm 126.9$ & 91.5 \\
& $6-9$ & $5,842.0$ & $1.4 \pm 0.5$ & 99.5 \\
& $0-3$ & $1,475.6$ & $16.4 \pm 4.0$ & 99.1 \\
\hline
\end{tabular}

${ }^{\text {a }}$ The concentrations from the control BSF A effluent were taken into account to determine the removal rates of BSF B:

Removal efficiency $\%=100-[($ BSF B effluent concentration-BSF A effluent concentration $) / B S F$ B influent concentration $) \times 100]$ 


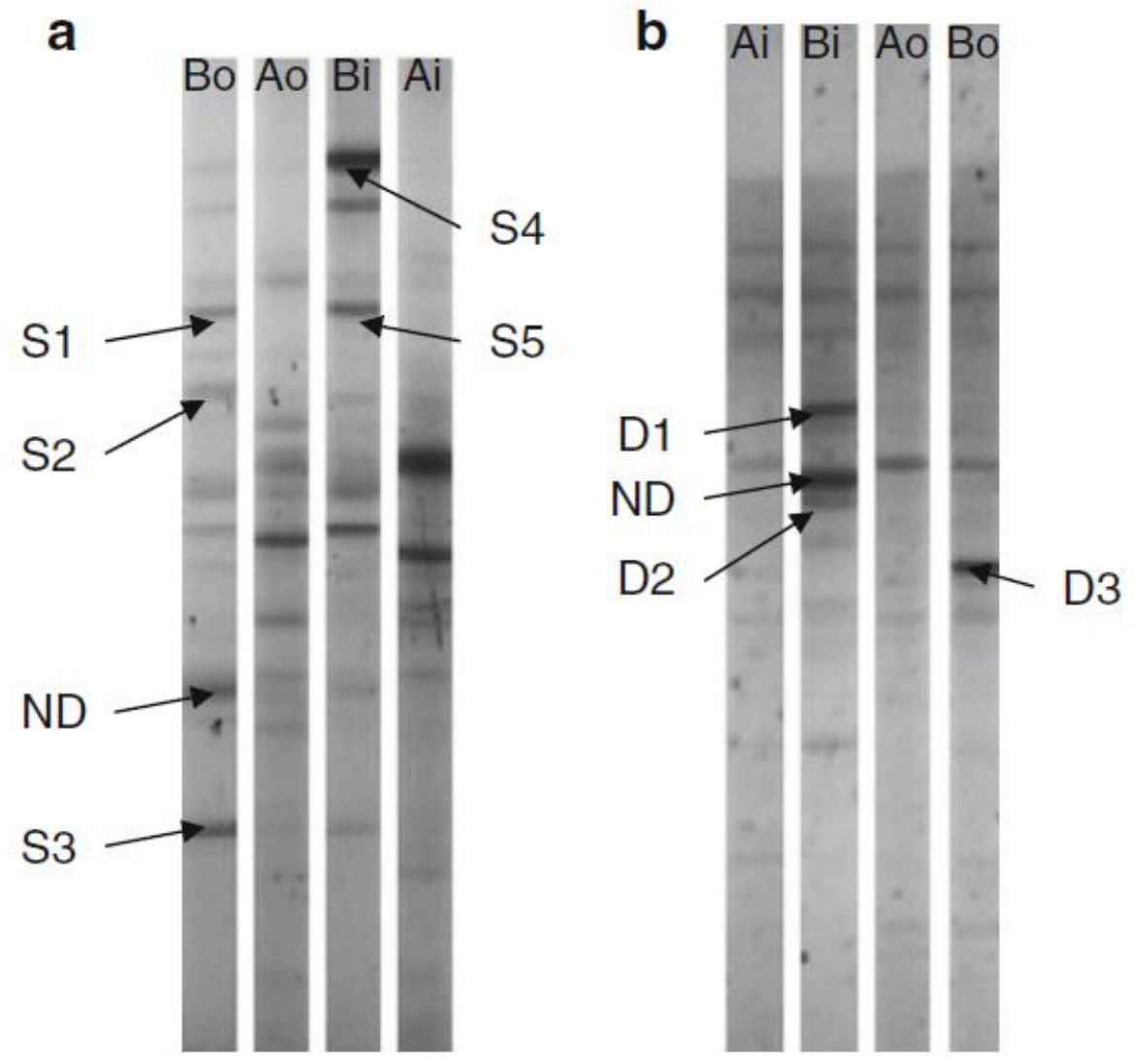

Fig. 2 Week 9 DGGE-gels of the surface (a) and deep (b) sediment bacterial communities of the biological sand filters. $A / B$ refers to the control BSF A and the phenolic-contaminated BSF B respectively. $i / o$ : inlet/outlet. Arrows and their associate references indicate DGGE bands excised, sequenced, and presented in Table 2; except ND which indicates excised DGGE bands with sequences not determined

In addition, it has been shown that acclimation/adaptation of the BSF microbial communities to phenolics and ethanol can be induced by increasing the influent strength over time [28, 29]. This paper principally focuses on the impact of the phenolic-rich synthetic wastewater on the BSF bacterial communities, as the experimental parameters associated with wastewater remediation performance have been published previously [29].

\section{Impact of Phenolic-Rich Wastewater on BSF Bacterial Community Structure}

When comparing the effect of pollutants on microbial communities in controlled environment mesocosms, it is essential that similar communities are established in each system before the start of the experiment. The similarity dendrogams presented in Fig. 1 show the clustering of the bacterial communities ( $91.3 \%$ similarity; Fig. 1a) derived from the surface and deep (100 and $91.6 \%$ at the inlet and outlet respectively; Fig. 1b) BSF sediments at day o. This confirms that the 3-month equilibration procedure generated highly similar communities in each BSF prior to experimentation (as previously demonstrated [19]), allowing confident comparative analysis of the phenolic WW impact on BSF bacterial communities.

\section{http://repository.uwc.ac.za}


Analysis of the DGGE patterns showed that during the course of the experiment, the bacterial communities in surface samples taken from weeks 3, 6 (BSFs A/B), and week 9 of the control BSF A grouped into two clusters sharing 58.5 \% similarity (Fig. 1a). However, these clusters only shared $31.6 \%$ similarity with the bacterial communities present at the end of the experiment (week 9) in BSF B. These results, together with effluent analyses, demonstrate that the functional bacterial communities in the surface of the BSF B initially adapted to increasing phenolic concentrations (up to 1,176.0 $\mathrm{mg} \mathrm{COD} \mathrm{L}^{-1}$ ) while maintaining excellent removal efficiency (Table 1). However, at the highest influent COD concentration $\left(5,842.0 \mathrm{mg} \mathrm{L}^{-1}\right.$; weeks $\left.7-9\right)$ the effluent phenolic concentration was high (Table 1) and there was a build-up of toxic metabolites, especially catechol, in the substratum [29] which elicited large changes in the bacterial community structure.

Table 2 Sequence similarities of excised DGGE bands shown in Fig. 2

\begin{tabular}{|c|c|c|c|c|}
\hline $\begin{array}{l}\text { DGGE Band } \\
\text { [accession } \mathrm{Nb}]\end{array}$ & BSF niche & Most closely related sequence [accession number] & $\begin{array}{l}\% \text { of identity } \\
(\text { nb of base })^{\mathrm{a}}\end{array}$ & Origin \\
\hline S1 [KC609353] & Surface outlet & $\begin{array}{l}\text { Beijerinckia indica strain SDSA-I30/2 [GU372346.1] and various } \\
\text { Azotobacter beijerinckii strains [EF100152.1] [EF100151.1] } \\
\text { [NR_042071.1] }\end{array}$ & $100 \%(152)$ & $\begin{array}{l}\text { Rice field soil } \\
\text { or type strains }\end{array}$ \\
\hline S2 [KC609354] & Surface outlet & Acetobacter woodii DSM 1030 strain [NR_074548.1] & $94 \%(151)$ & Type strain \\
\hline S3 [KC609355] & Surface outlet & Arthrobacter polychromogenes strain CT276 [HQ455829.1] & $98 \%(151)$ & $\begin{array}{l}\text { Rhizosphere of organic } \\
\text { olive grove }\end{array}$ \\
\hline S4 [KC609356] & Surface inlet & Pseudomonas fluorescens strain X [JQ361765.1] & $99 \%(153)$ & Greenhouse soil \\
\hline S5 [KC609357] & Surface inlet & $\begin{array}{l}\text { Beijerinckia indica strain SDSA-I30/2 [GU372346.1] and various } \\
\text { Azotobacter beijerinckii strains [EF100152.1] [EF100151.1] } \\
\text { [NR 042071.1] }\end{array}$ & $100 \%(152)$ & $\begin{array}{l}\text { Rice field soil or } \\
\text { type strains }\end{array}$ \\
\hline D1 [KC609358] & Deep inlet & $\begin{array}{l}\text { Beijerinckia indica strain SDSA-I30/2 [GU372346.1] and various } \\
\text { Azotobacter beijerinckii strains [EF100152.1] [EF100151.1] } \\
\text { [NR_042071.1] }\end{array}$ & $100 \%(152)$ & $\begin{array}{l}\text { Rice field soil or } \\
\text { type strains }\end{array}$ \\
\hline D2 [KC609359] & Deep inlet & $\begin{array}{l}\text { Azotobacter salinestris strain ATCC } 49674[\mathrm{JX} 680337.1] \text { and } \\
\text { Azotobacter } \mathrm{sp} . \text { Msn } 2[\mathrm{JX} 437936.1]\end{array}$ & $86 \%(151)$ & $\begin{array}{l}\text { Tea rhizosphere/ } \\
\text { farm soil }\end{array}$ \\
\hline D3 [KC609360] & Deep outlet & Various uncultured Geobacteraceae clones & $99 \%(154)$ & Soil \\
\hline
\end{tabular}

${ }^{a}$ The numbers in parentheses correspond to the number of based used to calculate the levels of sequence identity.

DGGE analyses of the deep sediment bacterial community structures showed three dispersed clusters with no clear impact of the phenolic-laden wastewater during the first 6 weeks of experimentation (Fig. 1b), confirming adaptation of the original communities to increasing phenolic concentrations.

A spatial impact of synthetic WW on the deep sediment communities was demonstrated at week 9. At this point, the deep inlet and outlet BSF B communities shared respectively $29.4 \%$ and $73.6 \%$ similarity with those of the control (BSF A). These results strongly suggest that the selective pressure experienced by the deep outlet sediment communities was significantly lower than that experienced by the surface (inlet/outlet) and deep inlet bacterial communities. It is hypothesized that plug flow of influent may have resulted in sequential degradation of the WW from inlet to outlet, so that the bacterial communities at the deep outlet were exposed to qualitatively and/or quantitatively less toxic chemicals.

\section{http://repository.uwc.ac.za}




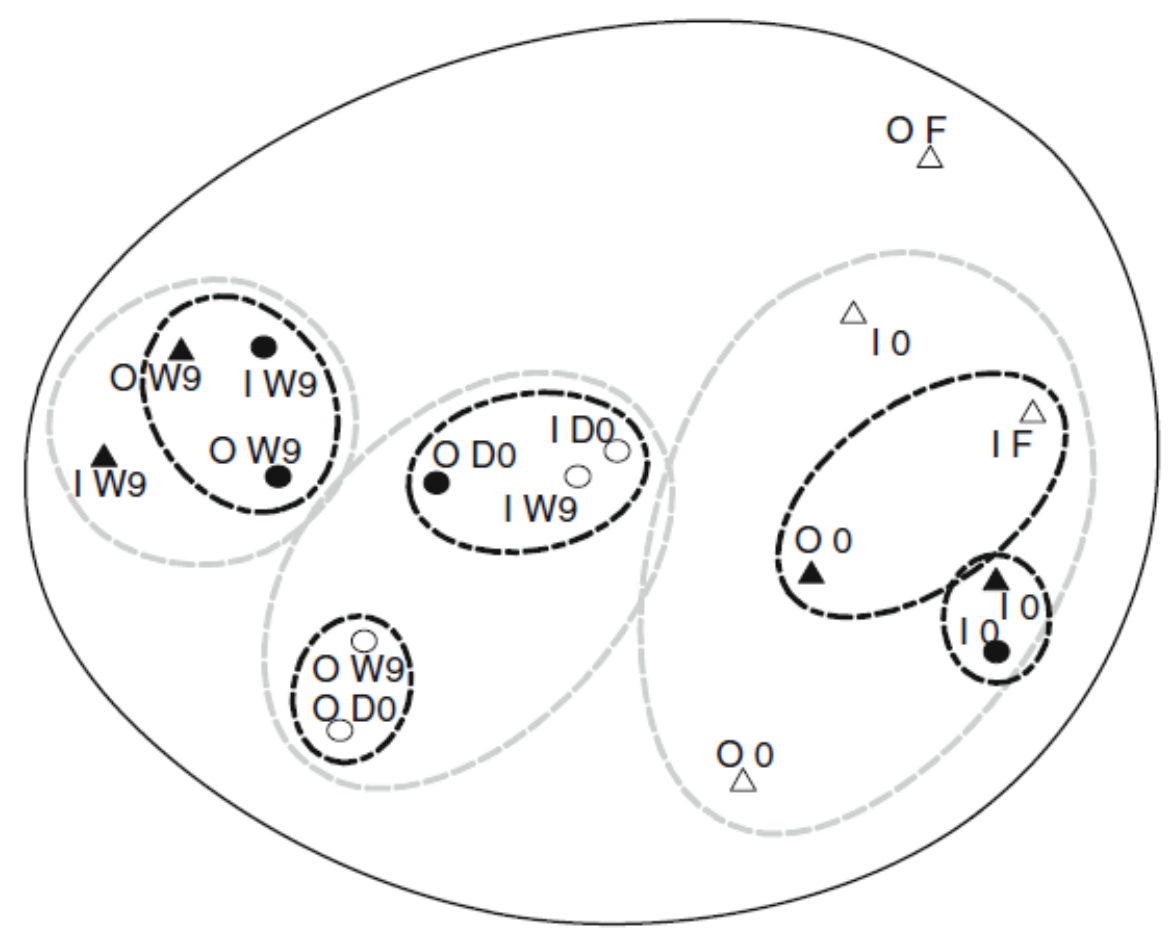

Fig. 3 2D-nonmetric multi-dimensional scaling plot of Bray-Curtis similarity of diazotrophic biological sand filter bacterial community structures determined by T-RFLP analysis of nifH genes (2D stress $=0.11$ ). The ellipses around the samples describe their level of similarity (black line $20 \%$; dashed gray $40 \%$; dashed black $60 \%$ ). Empty triangle, control surface; filled triangle, phenolic-contaminated surface; empty circle, control deep; filled circle, phenolic contaminated deep. $I$, inlet; $O$, outlet. $W 9$, week $9 ; D 0$, day 0

Together, these results demonstrated that despite using incremental priming, amendment with high-strength phenolic WW, such phenolic concentrations had a severe impact on the BSF bacterial communities in three of the four BSF ecological niches studied. Using a similar experimental procedure with ethanol as the sole organic contaminant, BSF bacterial communities demonstrated resistance to influent COD concentrations reaching $15,800 \mathrm{mg} \mathrm{L}^{-1}$, consistently reducing the COD to $<100 \mathrm{mg} \mathrm{L}^{-1}$ [28]. Comparison of these results with those obtained during amendment of the BSFs with phenolic WW clearly confirms that phenolicrich wastewater, such as OMWW, is highly toxic and that phenolics show a high level of recalcitrance to biodegradation [8].

\section{Identification of Phenolic-Selected Bacterial Phylotypes}

In DGGE fingerprints, each DGGE band is considered an OTU, and its intensity is proportional to the OTU's relative abundance in the total community investigated. In this study, 9 weeks of exposure to phenolic-rich wastewater substantially modified the BSF microbial community structures, with the disappearance, appearance and/or enhancement of OTUs (Figs. 1 and 2). Phenolic-selected DGGE bands from the week 9 fingerprint of BSF B, i.e., those which intensified or were only present in the community fingerprint of BSF B, were excised for further

\section{http://repository.uwc.ac.za}


identification. We successfully re-amplified and purified ten DGGE bands (indicated by arrows in Fig. 2), and phylogenetically identified eight by sequencing (Table 2); five from the surface samples (DGGE bands S1 to S5; Fig. 2a) and three from the deep samples (DGGE bands D1 to D3; Fig. 2b). Three of these were closely related to bacterial taxa with a known capability to degrade/oxidize organic and/or aromatic compounds (Pseudomonas fluorescens [DGGE band S4], Arthrobacter sp. [DGGE band S3], and Geobacter sp. [DGGE band D3]) [11, 32]. The selection of bacterial taxa possessing such catabolic capacities in BSF B was not unexpected, as it constitutes a direct community adaptation to the contamination [12, 15]. Four were, however, closely related to well-known nitrogen-fixing microorganisms (Azotobacter species/Beijerinckia indica [DGGE bands S1, S5, D1, D2]).

Table 3 Evolution of the nifH gene T-RFLP profile diversity indexes in the BSFs A (control) and B (phenolic-spiked) mesocosms

\begin{tabular}{|c|c|c|c|c|c|c|}
\hline \multirow[b]{2}{*}{ BSF niche } & \multicolumn{3}{|c|}{ Control BSF A (day 0/week 9) } & \multicolumn{3}{|c|}{ Phenolic-contaminated BSF B (day 0/week 9) } \\
\hline & $S$ & $H^{\prime}$ index & $E$ index & $S$ & $H^{\prime}$ index & $E$ index \\
\hline Surface inlet & $18 / 19$ & $2.792 / 2.841$ & $0.9659 / 0.9649$ & $14 / 10$ & $2.558 / 1.948$ & $0.9693 / 0.8461$ \\
\hline Surface outlet & $10 / 6$ & $2.230 / 1.738$ & $0.9683 / 0.9701$ & $16 / 7$ & $2.704 / 1.419$ & $0.9753 / 0.7291$ \\
\hline Deep inlet & $12 / 11$ & $2.461 / 2.367$ & $0.9905 / 0.9870$ & $18 / 10$ & $2.813 / 1.977$ & $0.9733 / 0.8588$ \\
\hline Deep outlet & $6 / 6$ & $1.776 / 1.768$ & $0.9912 / 0.9868$ & $8 / 7$ & $2.044 / 1.709$ & $0.9831 / 0.8785$ \\
\hline
\end{tabular}

It has previously been reported that diazotrophs are selected in organic-contaminated sediments [2]. Such adaptive traits indicate that bioavailable $\mathrm{N}$ is of pivotal importance for the bioremediation of organic-rich effluents and/or for organic-contaminated wholeecosystems to function effectively. The physiological costs for microbial communities to adapt/acclimate even to slight environmental changes can be great enough to impede ecosystem functioning [22]. This may translate into a reduction in bioremediatory performance of biological treatment processes, such as BSFs. This is confirmed by recent results showing that when exposed to organic-rich effluent supplemented with bioavailable nutrients (notably N), (1) BSF bacterial communities maintained their original community structures and (2) the BSF displayed better COD-removal performances than an experimental replicate which was not supplemented by $\mathrm{N}$ [20]. Together, this demonstrates that bioavailable $\mathrm{N}$ and thus diazotrophic communities are crucial in biological treatment processes.

\section{Evolution of the Diazotrophic Diversity in Phenolic-Contaminated BSF Sediments}

In order to better understand the dynamics of diazotrophic bacterial communities in BSF B (contaminated with phenolic WW), a T-RFLP approach targeting the phylogenetic marker nifH gene was adopted (Fig. 3, Table 3). The clustering of the samples in the nMDS plot presented in Fig. 3 clearly demonstrates significant differences between the samples representing the week 9 BSF B communities and the remainder of the samples (ANOSIM, Global $\mathrm{R}=0.475, \mathrm{P}=0.002$ ). The mean $\mathrm{H}^{\prime}$ and $\mathrm{E}$ diversity indexes were significantly lower $(\mathrm{P}<0.05$ and $\mathrm{P}<0.001$, respectively) in BSF B $(1.763 \pm 0.259$ and $0.8281 \pm 0.067$, respectively) than in the control BSF A (2.179 \pm 0.528 and $0.9772 \pm 0.0114$, respectively) (Table 3$)$. Together, these results clearly

\section{http://repository.uwc.ac.za}


indicate the selection of a specific, less diverse, and phenolic-resistant diazotrophic community in BSF B. In microcosm experiments, ecosystem stability (i.e., resistance and resilience) and function have been shown to be indifferent to the declining diversities of the total microbial community and of specific functional groups (denitrifiers and nitrite-oxidizers), respectively $[30,31]$. Therefore, it can be hypothesized that the resistant and specific (diazotrophic) BSF bacterial communities selected by phenolics, even at the highest influent concentrations, performed sufficiently for the BSF ecosystem to maintain its essential functions and processes (e.g., primary production and $\mathrm{N}$ fixation), despite failing remediatory performances.

\section{Conclusion}

Phenolic-rich wastewaters are highly toxic and therefore represent a treatment challenge in biological systems. In this study, we have demonstrated that applying increasing concentrations of phenolics to a treatment BSF resulted in a bacterial community response, with a notable selection for diazotrophs. The coupling of this response to an efficient phenolic removal suggested that the adapted and phenolic-selected diazotrophic BSF bacterial communities enabled the systems to achieve a desirable nutrient balance via self-regulation and that an adequate level of bioavailable nitrogen is crucial for biological treatment processes. Such a self-regulating system obviates the need for the addition of chemicals to achieve a particular $\mathrm{C} / \mathrm{N}$ ratio for optimal bio-degradation, which saves on material and labor costs and decreases the likelihood of excess $\mathrm{N}$ in the treated effluent. Therefore, when designing organic-treatment processes involving microbial communities, the presence of a pre-adapted diazotrophic community is an important factor to consider to minimize the energetic burden involved in the in vivo selection of alternative metabolic capacities (such as $\mathrm{N}$-fixing phylotypes), which might in turn enhance the efficiency of catabolic processes focused on the removal of the xenobiotic compounds.

\section{Acknowledgments}

This study was funded by the Water Research Commission of South Africa (WRC project K5/1725: Health for purpose in wetlands). J-BR held a Free-standing Postdoctoral Fellowship from the National Research Foundation (NRF) of South Africa. 


\section{References}

1. Babatunde AO, Zhao YQ, O'Neill M, O'Sullivan B (2008) Constructed wetlands for environmental pollution control: a review of developments, research and practice in Ireland. Environ Int 34:116-126

2. Chronopoulou P-M, Fahy A, Coulon F, Païssé S, Goñi-Urriza M, Peperzak L, Acuña Alvarez L, McKew BA, Lawson T, Timmis KN, Duran R, Underwood GJC, McGenity TJ (2013) Impact of a simulated oil spill on benthic phototrophs and nitrogen-fixing bacteria in mudflat mesocosms. Environ Microbiol 15:242- 252

3. Clarke K (1993) Non-parametric multivariate analysis of changes in community structure. Aust J Ecol 18:117-143

4. Culman SW, Bukowski R, Gauch HG, Cadillo-Quiroz H, Buckley DH (2009) T-REX: software for the processing and analysis of T-RFLP data. BMC Bioinforma 10:171

5. Faulwetter JL, Gagnon V, Sundberg C, Chazarenc F, Burr MD, Brisson J, Camper AK, Stein OR (2009) Microbial processes influencing performance of treatment wetlands: a review. Ecol Eng 35:987-1004

6. Haberl R, Grego S, Langergraber G, Kadlec RH, Cicalini A-R, Martins Dias S, Novais JM, Aubert S, Gerth A, Thomas H, Hebner A (2003) Constructed wetlands for the treatment of organic pollutants. J Soil Sedim 3:109-124

7. Haritash AK, Kaushik CP (2009) Biodegradation aspects of polycyclic aromatic hydrocarbons (PAHs): a review. J Hazard Mater 169:1-15

8. Herouvim E, Akratos CS, Tekerlekopoulou A, Vayenas DV (2011) Treatment of olive mill wastewater in pilot-scale vertical flow constructec wetlands. Ecol Eng 34: 931 -

9. Imfeld G, Braeckevelt M, Kuschk P, Richnow HH (2009) Monitoring and assessing processes of chemicals removal in constructed wetlands. Chemosphere 74:349-362

10. Kivaisi AK (2001) The potential for constructed wetlands for wastewater treatment and reuse in developing countries: a review. Ecol Eng 16:545-560

11. Le Roes-Hill M, Khan N, Burton SG (2011) Actinobacterial peroxidases: an unexplored resource for biocatalysis. Appl Biochem Biotechnol 164:681-713

12. Lu Z, He Z, Parisi VA, Kang S, Deng Y, Van Nostrand JD, Masoner JR, Cozzarelli IM, Suflita JM, Zhou J (2012) GeoChip-based analysis of microbial functional gene diversity in a land fill leachate-contaminated aquifer. Environ Sci Technol 46:5824-5833

13. Muyzer G, de Waal EC, Uitterlinden AG (1993) Profiling of complex microbial populations by denaturing gradient gel electrophoresis analysis of polymerase chain reaction-amplified genes coding for 16S rRNA. Appl Environ Microbiol 59:695-700

14. Mosse KPM, Patti AF, Christen EW, Cavagnaro TR (2010) Winery wastewater inhibits seed germination and vegetative growth of common crop species. J Hazard Mater 180:63-70

15. Niepceron M, Portet-Koltalo F, Merlin C, Motelay-Massei A, Barray S, Bodilis J (2010) Both Cycloclasticus spp. and Pseudomonas spp. as PAH-degrading bacteria in the Seine estuary (France). FEMS Microbiol Ecol 71:137-147

16. Paraskeva P, Diamadopoulos E (2006) Technologies for olive mill wastewater (OMW) treatment: a review. J Chem Technol Biotechnol 81:1475-1485

17. Poly F, Jocteur Monrozier L, Bally R (2001) Improvement in the RFLP procedure for studying the diversity of nifH genes in communities of nitrogen fixers in soil. Res Microbiol 152:95-103

\section{http://repository.uwc.ac.za}


18. Puupponen-Pimiä R, Nohynek L, Meier C, Kähkönen M, Heinonen M, Hopia A, OksmanCaldentey K-M (2001) Antimicrobial properties of phenolic compounds from berries. J Appl Microbiol 90:494-507

19. Ramond J-B, Welz PJ, Cowan DA, Burton SG (2012) Microbial community structure stability, a key parameter in monitoring the development of constructed wetland mesocosms during start-up. Res Microbiol 163:28-35

20. Rodriguez-Caballero A, Ramond J-B, Welz PJ, Cowan DA, Odlare M, Burton SG (2012) Treatment of high ethanol concentration wastewater by biological sand filters: enhanced COD removal and bacterial community dynamics. J Environ Manag 109:54-60

21. SAWIS (2009) South African Wine Industry Information and Systems. Macro-economic Impact of the Wine Industry on the South African Economy (also with reference to the Impacts on the Western Cape). Final Report. 62pp

22. Schimel J, Balser TC, Wallenstein M (2007) Microbial stress-response physiology and its implications for ecosystem function. Ecology 88:1386-1394

23. Serrano L, de la Vargo D, Ruiz I, Soto M (2010) Winery wastewater treatment in a hybrid constructed wetland. Ecol Eng 37:744-753

24. Smith VH, Tilman GD, Nekola JC (1999) Eutrophication: impacts of excess nutrient inputs on freshwater, marine, and terrestrial ecosystems. Environ Pollut 100:179-196

25. Verhoeven JTA, Arheimer B, Yin C, Hefting MM (2006) Regional and global concerns over wetlands and water quality. Trends Ecol Evol 21:96-103

26. Vossen P (2007) Olive oil: history, production, and characteristics of the world's classic oils. Hortscience 42:1093-1100

27. Vymazal J, Kröpfelová L (2009) Removal of organics in constructed wetlands with Horizontal sub-surface flow: a review of the field of experience. Sci Total Environ 407:3911- 3922

28. Welz PJ, Ramond J-B, Cowan DA, Prins A, Burton SG (2011) Ethanol degradation and the benefits of incremental priming in pilot-scale constructed wetlands. Ecol Eng 37:14531459

29. Welz PJ, Ramond J-B, Cowan DA, Burton SG (2012) Phenolic removal processes in biological sand filters, sand columns and microcosms. Bioresource Technol 119:262-269

30. Wertz S, Degrange V, Prosser JI, Poly F, Commeaux C, Freitag T, Guillaumaud N, Le Roux $\mathrm{X}$ (2006) Maintenance of soil functioning following erosion of microbiol diversity. Environ Microbiol 8:2162-2169

31. Wertz S, Degrange V, Prosser JI, Poly F, Commeaux C, Guillaumaud N, Le Roux X (2007) Decline of soil microbial diversity does not influence the resistance and resilience of key microbial functional groups following a model disturbance. Environ Microbiol 9:22112219

32. Widdel F, Rabus R (2001) Anaerobic biodegradation of saturated and aromatic hydrocarbons. Curr Opin Biotechnol 12:259-276 